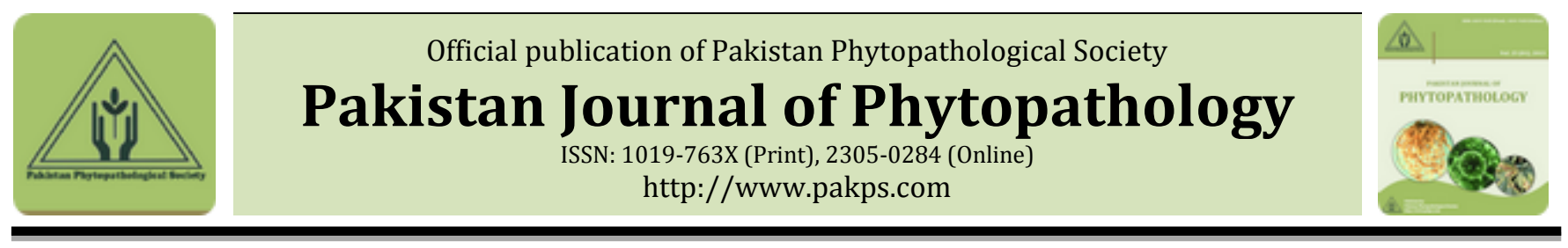

\title{
ANTAGONISTIC POTENTIAL OF TRICHODERMA HARZIANUM AGAINST FUSARIUM OXYSPORUM F. SP. CUBENSE ASSOCIATED WITH PANAMA WILT OF BANANA
}

\author{
aBabar Khan, aZuniara Akash, bShahzad Asad, aNazir Javed, aNasir A. Rajput, aAbdul Jabbar, cWasi U. Din, dRana M. Atif \\ aDepartment of Plant Pathology, University of Agriculture, Faisalabad, Pakistan. \\ ${ }^{b}$ Crop Disease Research Institute, National Agricultural Research Center, Islamabad, Pakistan. \\ 'Department of Agronomy, University of Agriculture, Faisalabad, Pakistan. \\ dDepartment of Plant Breeding and Genetics / USPCAS-AFS, University of Agriculture, Faisalabad, Pakistan.
}

\section{A B S T R A C T}

Fusarium oxysporum f. sp. cubense is a soil loving pathogen of banana that can cause distortion of vascular system. It is responsible for the disease Fusarium wilt of bananas also renowned as panama wilt disease that has responsible of immense losses in the banana industry worldwide. In this study, diseased samples were collected from rhizosphere of banana plants in the research area of National Agriculture Research Centre (NARC), Islamabad and cultured on PDA to isolate pathogenic strains of $F$. oxysporium f. sp. cubense. Antagonistic potential of Trichoderma harzianum against $F$. oxysporum f. sp. cubense was evaluated under controlled conditions. T. harzianum produced up to $75.5 \%$ inhibition of colony growth of the pathogen followed by incubation for $72 \mathrm{~h}$ at $28+2^{\circ} \mathrm{C}$ in vitro. In pot culture T. harzianum considerably reduced disease severity. It proves that it is a potential biological control agent against banana wilt pathogen.

Keywords: Biological control, Fusarium wilts, Inhibition, Pot culture

\section{INTRODUCTION}

Banana (Musa sp.) is an important fruit crop of Pakistan. It is cultivated on 34,8000 hectares with 154,8000 tons annual production (FAO, 2011). Due to favorable soil and climatic conditions, it is successfully cultivated in Sindh province. Its 87 percent production from Sindh and $13 \%$ from the whole country (Roberts et al., 2012). Banana is the earliest crop cultivated by man and still world's most main cash crop (Molina and Valmayor, 1999). It is cultivated more than 120 countries in subtropical and tropical regions of the world and now more than 400 million people use as staple food (Molina and Valmayor, 1999). It is a perennial monocotyledon plant belongs to the family Musaceae. It is mostly cultivated in areas situated between $30^{\circ} \mathrm{N}$ and $30^{\circ} \mathrm{S}$ latitudes (Bentley et al., 1998). Export of dessert banana is the main fruit in the international fruit trade and the most popular fruit in the world (Anania, 2006). Banana production is a major source of income and is an

* Corresponding Author:

Email: babarkhan.uaf@gmail.com

(C) 2017 Pak. J. Phytopathol. All rights reserved. essential source of food for more than 70 million people in Africa (Rutherford and Viljoen, 2003).

Fusarium wilts also known as panama wilt caused by Fusarium oxysporum f. sp. cubense is a major constraint to banana production worldwide. It is active saprophyte in organic matter, soil and several forms are pathogenic to plants (Smith et al., 1988). This pathogen survives and spread through infested soil and infected plants. It can infect fruits and seeds but dispersal through seed is very rare (Agrios, 2005). Characteristic symptoms of $F$. oxysporum f. sp. cubense infection are discoloration or browning of foliar plant tissues. However, symptoms are more obvious on old plant during flowering stage and fruit maturity stages (Smith et al., 1988). The fungus causes root rot, vascular wilt and damping off in a number of plant species (Saremi et al., 1996).

F. oxysporum f. sp. cubense cause vascular wilt syndrome in banana and during 1960s it demolished whole banana industry (Leslie et al., 2006). This fungus has many famous plant pathogenic strains and $F$. oxysporum the cause of panama wilt have four different races. Control of soil borne phytopathogens through biological control 
agents is effective way (Rakh et al., 2011). Only one application of a biological control agent as seed treatment reduces the seed decay and damping off of seedlings while controlling such, diseases mainly depend on fungicides treatments (Ahmad et al., 2009). Application of fungicides hazardous for environment and human health, therefore, environment friendly approach against pathogens required for safety (Rojo et al., 2010). Many studies have proved the potential of Trichoderma spp. as biological agent antagonistic behavior to several plant pathogens (Sivan and Chet, 1993).

Among different bio control agents Trichoderma spp. are common free-living fungi present in roots and soil. Trichoderma species is very interactive to root, soil and plant foliar environments. Due to release of different compounds it triggers the plant immune system and resistance in the form of local or systemic. Trichoderma is well recognized as biological weapon against different plant pathogens and used as growth regulator for roots, yield increase, flexibility towards stress and nutrients uptake from soil. Trichoderma spores are more tolerant against unfavorable environmental conditions when used in the form of product formulation and field applications (Amsellem et al., 1999). Presence of mycelia mass plays a key role in antagonistic metabolites (Benhamou and Chet, 1993; Yedidia et al., 2000). The objective of this study was to evaluate the efficacy of $T$. harzianum against $F$. oxysporum f. sp. cubense and to detect and quantify the reduction in pathogen population.

\section{MATERIALS AND METHODS}

Isolation and Multiplication of Pathogen: Pathogen was isolated from infected banana plants in fungal pathology laboratory of Crop Disease Research Institute of National Agriculture Research Centre (NARC) Islamabad. Small pieces of infected tissues were surface sterilized with $1 \%$ sodium hypochlorite and rinsed within distilled water thrice then dried on blotter paper to remove excess moisture. After that 4 5 , infected pieces were placed on petri plates in a laminar flow chamber containing PDA media and incubated at $25^{\circ} \mathrm{C}$ for one week. After two days of incubation, bud tip of fungal mycelium was isolated and transfer to the new petri plates for purification. Pathogen identified was confirmed microscopically through illustrated genera of imperfect fungi (Barnett and Hunter, 1972) while T. harzianum culture was obtained from culture bank of mycology lab of NARC.
Dual Culture Technique: Colony interaction of $F$. oxysporum and T. harzianum was studied on PDA containing plates by using dual culture method (Skidmore and Dickinson, 1976). The growth inhibition in the colony of the test pathogen and the antagonistic fungi was calculated and interaction grade have been determined as proposed by formula (Porter, 1924).

$$
\text { Percentage growth inhinition }=\frac{r-r 1}{r} \times 100
$$

$r=$ radius of fungal colony without antagonist towards the center of the plate

$r_{1}=$ radius of the fungus colony from centre towards the antagonistic

Culture filtrate assay: Potato dextrose broth $100 \mathrm{ml}$ was inoculated with antagonist culture blocks obtained from the actively growing margins followed by incubation at $28 \pm 2^{\circ} \mathrm{C}$ for 15 days, after which the hyphal mat of each fungus was filtered first through whatman filter paper 1 and finally through millipore filter paper. Culture filtrate was evaluated against pathogen at four different concentrations $5,10,15$ and $20 \%$ in petri plates. Pathogen $5 \mathrm{~mm}$ culture blocks were inoculated at the center of the plates. The plates were incubated at $28 \pm 2^{\circ} \mathrm{C}$ for five days and the radial growth was recorded periodically.

The percentage inhibition of growth was calculated as follows:

$$
\text { Percent growth inhibition }=\frac{g 1-g^{2}}{g 1} \times 100
$$

$\mathrm{g} 1=$ Growth in control

g2 $=$ Growth under treatment

Pot Culture Assay: Soil taken from field was autoclaved at $121^{\circ} \mathrm{C}$ for 20 minutes at $15 \mathrm{psi}$ to kill bacteria and other microorganisms. The inoculum was prepared by growing a culture of $F$. oxysporum in a modified liquid broth czapek's Dox (CD) and mixed with autoclaved soil (Esposito and Fletcher, 1961). The mixture was incubated eight weeks at room temperature to allow the fungus to colonize the medium extensively. Banana seedlings of the variety Dwarf Cavendish were taken from tissue culture lab of NARC and transplanted in pots for evaluation. The both fungal spore suspension was made in 1 liter distilled water for inoculation separately. Spore was counted by using heamocytometer. Only freshly prepared inoculums were used. The following treatments were used to evaluate the effectiveness of antagonist: 
$\mathrm{T} 1=$ Seedlings were soaked in the water then transplanted into the pots treated with $F$. oxysporum inoculums

$\mathrm{T} 2=$ Seedling roots were soaked in water then in $T$. harzianum suspension and after transplanted into the pots treated with $F$. oxysporum inoculums

T3= Seedlings soaked $1^{\text {st }}$ with $F$. oxysporum then were inoculated after one week of transplantation with antagonist fungi

$\mathrm{T} 4=$ Seedlings roots were soaked $1^{\text {st }}$ with antagonist suspension and then inoculated with $F$. oxysporum after one week of transplantation

$\mathrm{T} 5=$ Seedlings roots were soaked in sterilized water and then transplanted into the pots containing sterilized soil. Data was recorded after 4-6 weeks of transplantations when symptoms start and compared with control

Disease rating scale: The disease development in controlled conditions was evaluated 4-6 weeks after inoculation using the disease incidence scale 0-5 which is 0 - immune 1- healthy, 2- slight chlorosis and wilting with no petiole buckling, 3- moderate chlorosis and wilting with some petiole buckling and or splitting of leaf bases, 4- severe chlorosis, severe wilting, petiole buckling and dwarfing of newly emerged leaf, 5completely dead (Ploetz et al., 1999). Percentage disease incidence for pot culture assay was calculated using the formula of Sherwood and Hagedorn (1958):

$\%$ disease incidence $=\frac{\text { Number of diseased plants }}{\text { Total number of Plants }} \times 100$

\section{STATISTICAL ANALYSIS}

Experimental design Complete Randomized Design (CRD) was used. Experimental results were analyzed by using statistix ver. 8.1. Software. The results were compared through Least significant difference (LSD) between means at $\mathrm{P} \leq 0.05$ (Steel et al., 1997).

\section{RESULTS}

Evaluation of $T$. harzianum against $F$. oxysporum by using dual culture technique: The maximum colony inhibition of $F$. oxysporum due to T. harzianum was $75 \%$. The mycelium of $T$. harzianum was found growing over the pathogen (Figure 1). T. harzianum showed best results against $F$. oxysporum in dual culture technique.

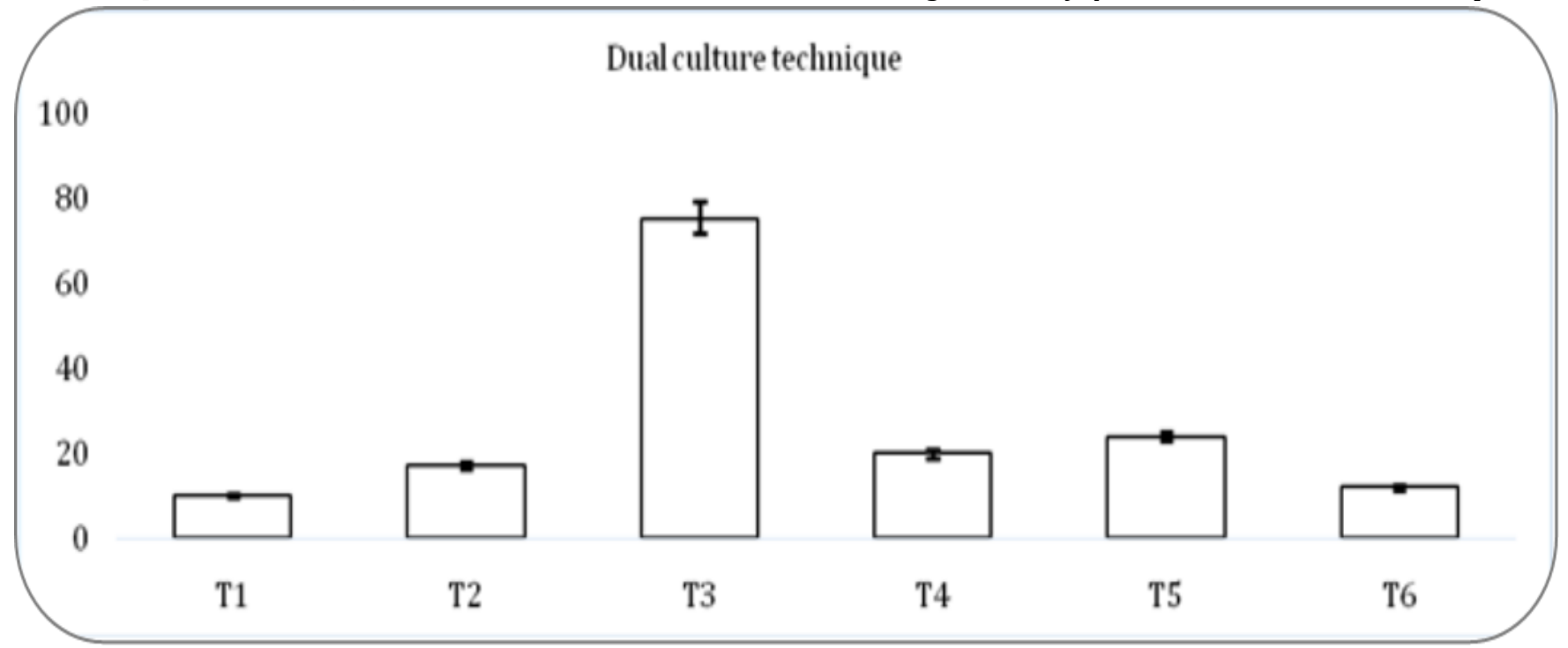

Figure 1. Colony interaction between $F$. oxysporum and $T$. harzianum in dual culture experiment. T1= Colony growth of pathogen towards antagonist $(\mathrm{mm}), \mathrm{T} 2=$ Colony growth of pathogen away from the antagonist, $\mathrm{T} 3=$ growth inhibition of the pathogen in the zone of interaction $(\mathrm{mm}), \mathrm{T} 4=$ Colony growth of antagonist towards the center pathogen $(\mathrm{mm}), \mathrm{T} 5=$ Colony growth of antagonist away from the pathogen $(\mathrm{mm})$ and $\mathrm{T} 6=\%$ of growth inhibition in the zone of interaction.

Evaluation of $T$. harzianum against $F$. oxysporum by using culture filtrate assay: The percentage inhibition of $F$. oxysporum in culture filtrate method was evaluated. Results indicate that the concentration of culture filtrate at $20 \%$ was more effective as compare to 5, 10 and $15 \%$ and inhibit the growth of $F$. oxysporum $75.5 \%, \quad 19.33 \%, \quad 23.33 \%$ and $31.33 \%$ respectively. The maximum inhibition of $F$. oxysporum was recorded in $20 \%$ culture filtrate of $T$. harzianum $75.5 \%$ (Figure 2).. The results showed that increasing level of inoculums of antagonist increase the inhibition of pathogen. 


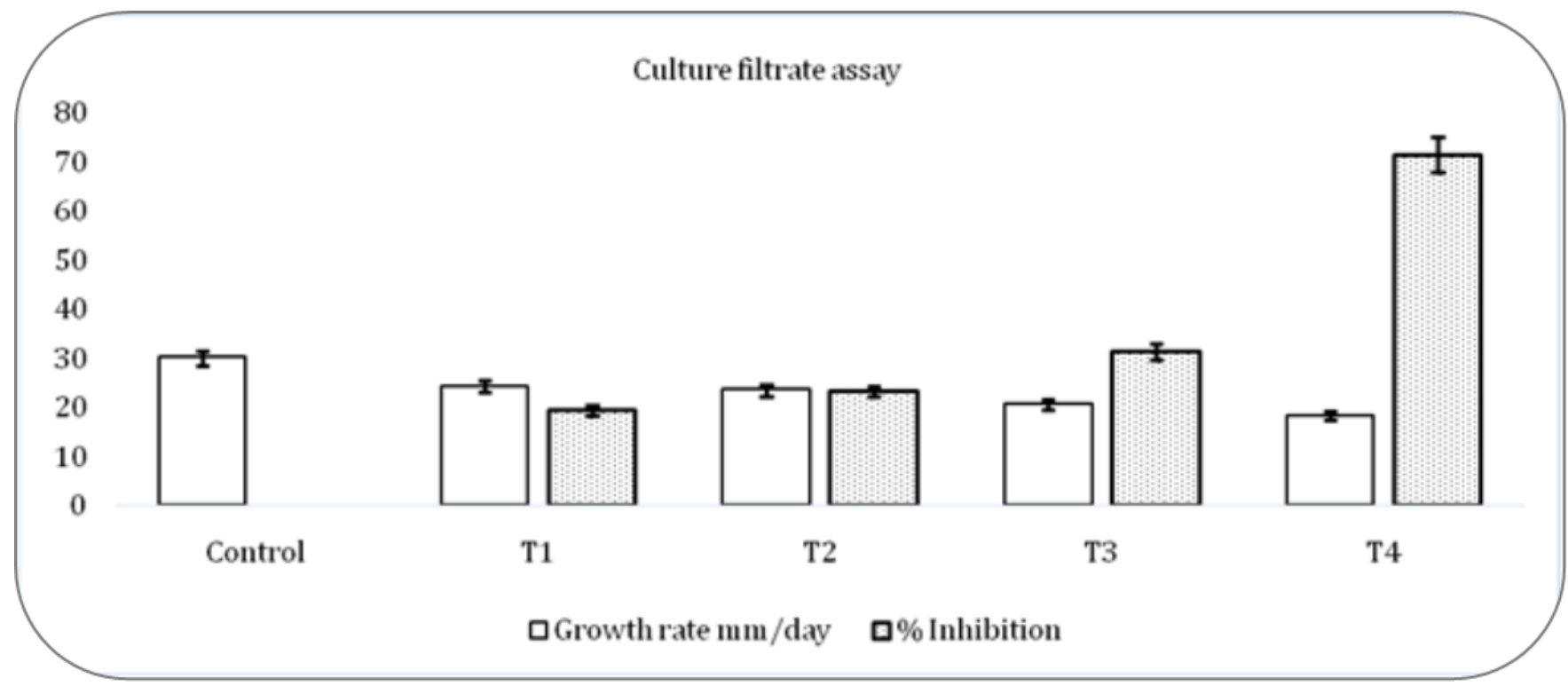

Figure 2. Effect of culture filtrate of $T$. harzianum towards growth of $F$. oxysporum. T1= 5\%, T2= 10\%, T3= $15 \%$ and $\mathrm{T} 4=20 \%$ concentration of $T$. harzianum against $F$. oxysporum.

Evaluation of $\boldsymbol{T}$. harzianum against $\boldsymbol{F}$. oxysporum in performing pot culture assay and the minimum disease pot culture assay: The maximum disease incidence incidence $16.66 \%$ was recorded in seedlings which first was recorded $83.33 \%$ in the F. oxysporum alone while $\quad$ inoculated with T. harzianum showed in (Figure 3).

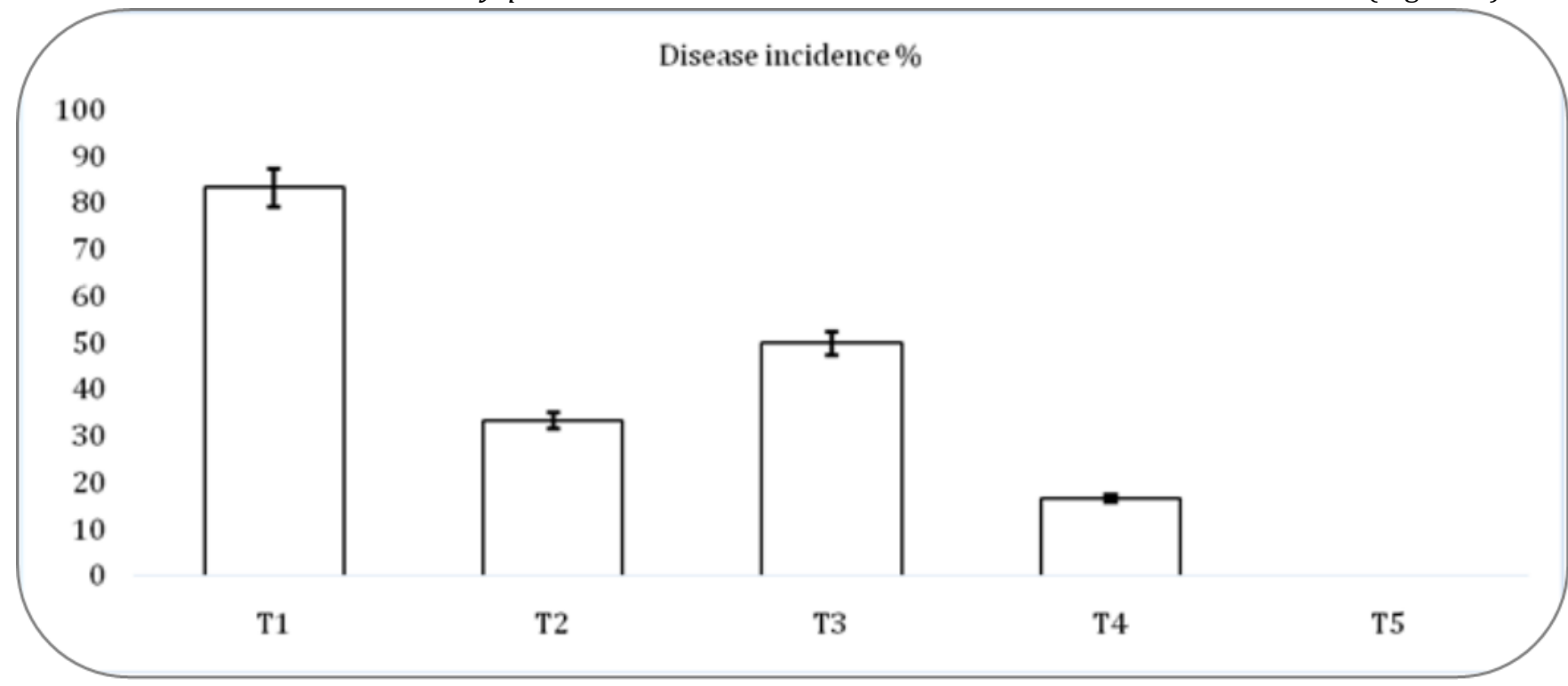

Figure 3. Evaluation of percentage disease incidence by using pot culture assay. $\mathrm{T} 1=F$. oxysporum, $\mathrm{T} 2=F$. oxysporum + T. harzianum culture, T3= First $F$. oxysporum culture + after 1 week interval $T$. harzianum culture, T4= First

T. harzianum culture + after 1 week interval $F$. oxysporum culture and T5= control

\section{DISCUSSION}

Due to residual effects of chemicals there is an increased trend of prevention through resistance development with the help of utilization of biological products particularly Trichoderma spp. which is recognized as potential bio control agent as a commercial bio-fungicides around the world (Harman et al., 2004; Lorito et al., 2010). Trichoderma are free living fungi and usually found in a diverse soil types such as forest, agriculture, prairie, desert soil and salt marsh (Albert et al., 2011). Aggregate species of Trichoderma can be distinguished based on macro and microscopic features. The antagonistic properties of Trichoderma spp. against different pathogens have also been reported 
(Panneerselvam and Saravanamuthu, 1994; Ambikapathy et al., 2000).

In dual culture technique results revealed that Trichoderma spp. exhibited the maximum reticence of pathogen mycelial growth. During inhibition zone in dual culture distance between hyphae of both fungi suggests that some secretion which are diffusible non-volatile inhibitory material produced by the Trichoderma isolate. Trichoderma specie interacts and produces small quantities of extracellular exochitinases (Kullnig et al., 2000; Brunner et al., 2003). T. harzianum inhibits the growth of $F$. oxysporum $(61.4 \%)$ in the dual culture technique described by (Muthukumar et al., 2006).

The maximum inhibition of $F$. oxysporum was recorded in $20 \%$ culture filtrate of $T$. harzianum $75.5 \%$ showed in (Figure 2). T. harzianum significantly $(\mathrm{P}<0.05)$ reduce the growth of $F$. oxysporum, on PDA after incubation for $72 \mathrm{~h}$ at $30^{\circ} \mathrm{C}$ reported (Ullah et al., 2011). Researchers reported that Trichoderma release different antibiotics which are trichodernin, trichodermol, harzianum A and harzianolide (Howell, 1998; Kucuk and Kivanc, 2004). Some cell wall degrading enzymes which are chitinases, glucanases that break down polysaccharides, chitins and glucanase, there by destroying cell wall reliability (Lorito et al., 1996; Harman and Kubicek, 1998; Woo et al., 2006). The maximum disease incidence was recorded $83.33 \%$ while performing pot culture assay showed in (Figure 3). In addition, the soil application of Trichoderma isolate increased the plant growth significantly $(\mathrm{P} \leq 0.05)$ compared to $F$. oxysporum alone inoculated. The pot culture evaluation carried out for rhizospheric Trichoderma against Fusarium wilt showed that the $T$. harzianum significantly $(\mathrm{P} \leq 0.05)$ reduced the Fusarium wilt disease severity (Srivastava et al., 2010).

\section{REFERENCES}

Agrios, G.N. 2005. Plant Pathology (Vol. 5). Burlington, MA: Elsevier Academic Press.

Ahmed, Z.M., S. Dawar and M. Tariq. 2009. Fungicidal potential of some local tree seeds for controlling root rot disease. Pak. J. Bot. 41(3): 1439-1444.

Albert, S., D. Chauhan, B. Pandya and A. Padhiar. 2011. Screening of Trichoderma spp. as potential fungal partner in co-culturing with white rot fungi for efficient bio-pulping. Glob. J. Biotechnol. Biochem. 95-101.

Ambikapathy, V. 2000. Studies on the saprophytic behaviors and suppression of Rhizoctonia solani kuhn, a broad-spectrum pathogen, Ph.D. Thesis,
Bharathidasan University, Tiruchirappalli, Tamil Nadu, India.

Amsellem, Z., N.K. Zidack, P.C. Quimby and J. Gressel. 1999. Long-term dry preservation of viable mycelia of two mycoherbicidal organisms. Crop Prot. 18: 643649.

Anania, G. 2006. The 2005 WTO arbitration and the new EU import regime for bananas: a cut too far? Eur. Rev. Agric. Econ. 33(4): 449-484.

Barnett, H.L and B.B. Hunter 1972."Illustrated genera of imperfect fungi."(3rd Edn).

Benhamou, N. and I. Chet. 1993. Hyphal interactions between Trichoderma harzianum and Rhizoctonia solani: Ultrastructure and gold cytochemistry of the mycoparasitic process. Phytopathol. 83: 1062-1071

Bentley, P.J. 1998. Comparative vertebrate endocrinology. Cambridge University Press.

Brunner K, C.K. Peterbauer, R.L. Mach, M. Lorito, S. Zeilinger and R.L.Kubicek. 2003. The Nacetylglucosaminidase of Trichoderma atroviride is essential for chitinase induction by chitin and major relevance to bio-control. Curr. Gen. 43: 289-295.

Esposito, R.G and A.M. Fletcher. 1961. The relationship of pteridine biosynthesis to the action of copper 8hydroxyquinolate on fungal spores. Arch. Biochem. Biophy. 93(2): 369-376.

FAO. 2011. FAO Stat Database Collection http://apps.fao.org/ page/collection (accessed on 17-06-2015).

Harman, G.E and C.P. Kubicek. 1998. Trichoderma and Gliocladium. Enzymes, biological control and commercial applications. Taylor \& Francis, London. 2:393.

Harman, G.E., C.R. Howell, A. Viterbo, I. Chet and M. Lorito. 2004. Trichoderma species opportunistic, avirulent plant symbionts. Nat. Rev. Microbiol. 2: 43-56.

Howell, C.R. 1998. The role of antibiosis in biocontrol. In Trichoderma and Gliocladium, Ed. C. P. Kubicek and G. E. Harman. London, Bristol, PA: Taylor \& Francis. 173-184.

Kucuk, C and M. Kivan. 2004. In vitro antifungal activity of strains of Trichoderma harzianum. Turk. J. Biol. 28: 111-115.

Kullnig, C., R.L. Mach, M. Lorito and C.P. Kubicek. 2000. Enzyme diffusion from Trichoderma atroviride to Rhizoctonia solani is a prerequisite for triggering of Trichodermae ech42 gene expression before 
mycoparasitic contact. Appl. Environ. Microbiol. 66: 2232-2234.

Leslie, J.F., B.A. Summerell and S. Bullock. 2006. The Fusarium laboratory manual. Vol. 2, No. 10. Ames, IA, USA: Blackwell Pub.

Lorito, M., S.L. Woo, E. Gary, G.E. Harman and E. Monte. 2010. Translational research on Trichoderma: From 'Omics to the Field. Ann. Rev. Phytopathol. 48: 395417.

Lorito, M., S.L. Woo, M. D. Ambrosio, G.E. Harman, C.K. Hayes, C.P. Kubicek and F. Scala. 1996. Synergistic interaction between cell wall degrading enzymes and membrane affecting compounds. Mol. Plant Microb. Interact. 9: 206-213.

Molina, A.B and R.V. Valmayor. 1999. Banana production systems in South East Asia. Bananas and Food security, Pica C., E. Foure, EA Frison (Eds.), INIBAP, Montpellier, France. 423-436.

Muthukumar, C., R. Vijayakumar, T. Kumar, A. Panneerselvam, N. Nadimuthu and R. Saravanamuthu. 2006. Studies on antagonism of some soil fungi against Drechslera ellisiia Fruit Rot Causing Organism in Guava. J. Soil Biol. 26: 117-122.

Panneerselvam, A and R. Saravanamuthu. 1994. Studies on antagonistic interaction of some soil fungi against Fusarium moniliforme. J. Ind. Bot. Soc. 73: 265-67.

Porter, C.L. 1924. Concerning the characters of certain fungi as exhibited by their growth in the presence of other fungi, AM. J. Bot. 11: 168-188.

PloetzR.C, J.L Haynes and A. Vazquez. 1999. Responses of new banana accessions in South Florida to Panama disease. Crop Prot. 18: 445-449

Rakh, R.R., L.S. Raut, S.M. Dalvi and A.V. Manwar. 2011. Biological control of Sclerotium rolfsii, causing stem rot of groundnut by Pseudomonas cf. monteilii 9. Rec. Res. Sci. Technol. 3:3.

Roberts, A., H. Nazli, M. Wach and Y. Zafar. 2012. An analysis of the development and regulation of agricultural biotechnology in Pakistan.

Rojo, N., G. Gallastegi, A. Barona, L. Gurtubay, G. IbarraBerastegi and A. Elías. 2010. Biotechnology as an alternative for carbon disulfide treatment in air pollution control. Environ. Rev. 18: 321-332.

Rutherford, M. and A. Viljoen. 2003. Fusarium wilt of banana in Africa current status, recent research and management prospects. Presentation at: International Fusarium Wilt Symposium, Salvador, Brazil. CABI International, Egham, UK.

Saremi, F., G. Lange and B. Tieke. 1996. Deeply colored self-assembled multilayers of anionic DPP bolaamphiphiles and cationic polyelectrolytes. Adv. Mater. 8(11): 923-926.

Sherwood, R.T and D.J. Hagedorn. 1958. Determining common root rot potential of pea fields.

Sivan, A and I. Chet. 1993. Integrated control of Fusarium crown and root rot of tomato with Trichoderma harzianum in combination with methyl bromide or soil solarization. Crop Prot. 12(5): 380-386.

Skidmore, A.M and C.M. Dickson. 1976. Colony interactions and hyphae interferences between Septoria nodorum and phylloplane fungi. Trans. Br. Mycol. Soc. 66: 57-64.

Smith, A.G., J.K. Heath, D.D. Donaldson, G.G. Wong, J. Moreau, M. Stahl and D. Rogers. 1988. Inhibition of pluripotential embryonic stem cell differentiation by purified polypeptides. Nature. 336(6200): 688690.

Srivastava, R., A. Khalid, U.S. Singh and A.K. Sharma. 2010. Evaluation of arbuscular mycorrhizal fungus, fluorescent Pseudomonas and Trichoderma harzianum formulation against Fusarium oxysporum f. sp. lycopersici for the management of tomato wilt. Biol. Cont. 53(1): 24-31.

Steel, R.D.D., J.H. Torrie and D. Dicky. 1997. Principles and Procedures of Statistics: A Biometrical Approach.

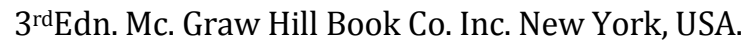

Ullah, M.H., M.A. Khan, S.T. Sahi and A. Habib. 2011. Evaluation of antagonistic fungi against charcoal rot of sunflower caused by Macrophomina phaseolina (Tassi) Goid. African J. Environ. Sci. Technol. 5(8): 616-621.

Woo, S.L., F. Scala, M. Ruocco and M. Lorito. 2006. The molecular biology of the interactions between Trichoderma spp. Phytopathogenic fungi and plants. Phytopathol. 96: 181-185.

Yedidia, I., N. Benhamou, Y. Kapulnik and I. Chet. 2000. Induction and accumulation of PR proteins activity during early stages of root colonization by the mycoparasite Trichoderma harzianum strain T-203. Plant Physiol. Biochem. 38: 863-873. 